\title{
Preoperative platelet count predicts posttransplant portal vein complications in orthotopic liver transplantation: a propensity score analysis
}

Qingshan $\mathrm{Li}^{1,2}$, Yue Wang ${ }^{1,2}$, Tao Ma ${ }^{1,2}$, Fenggang Ren ${ }^{1,2}$, Fan $\mathrm{Mu}^{1,2}$, Rongqian $\mathrm{Wu}^{1,2}, \mathrm{Yi} \mathrm{LV}^{1,2^{*}}$ and Bo Wang ${ }^{1,2^{*}}$

\begin{abstract}
Background: The role of platelets on the prognosis of patients with liver transplantation remains unclear. Thus, we aimed to evaluate the influence of preoperative platelet count on postoperative morbidity after liver transplantation.

Methods: Clinical data of the patients who received liver transplantation from January 2015 to September 2018 were evaluated.

Results: Of the 329 patients included, the average age was $46.71 \pm 0.55$ years, and 243 were men (75.2\%). The incidence of posttransplant portal vein complication was significantly higher in the high platelet count group $\left(>49.5 \times 10^{9} / \mathrm{L} ; n=167\right)$ than in the low platelet count group ( $\leq 49.5 \times 10^{9} / \mathrm{L}, n=162,12.6 \%$ vs. $\left.1.9 \%\right)$. After multivariable regression analysis, high platelet count was independently associated with postoperative portal vein complication (odds ratio [OR]: 8.821, 95\% confidence interval [CI]: 2.260 to 34.437). After the inverse probability of treatment weighting analysis, patients in the high platelet count group had significantly higher risk of portal vein complication (OR: $9.210,95 \% \mathrm{Cl}: 1.907$ to $44.498, p=0.006$ ) and early allograft dysfunction (OR: 2.087, 95\%Cl: 1.131 to 3.853 , $p=0.019$ ).
\end{abstract}

Conclusions: Preoperative platelet count $>49.5 \times 10^{9} / \mathrm{L}$ was an independent risk factor for posttransplant portal vein complication and early allograft dysfunction. High preoperative platelet count could be an adverse prognostic predictor for liver transplantation recipients.

Keywords: Preoperative platelet count, Liver transplantation, Portal vein complication, Inverse probability of treatment weighting

\section{Background}

Liver transplantation is considered the only therapeutic option for patients with end-stage liver disease. In the past decades, the outcome of liver transplantation has been dramatically improved with the development of surgical techniques, immunosuppression, and perioperative

*Correspondence: luyi169@126.com; bobwang75@126.com

${ }^{2}$ Department of Hepatobiliary Surgery, First Affiliated Hospital, Xi'an

Jiaotong University, Xi'an, Shaanxi Province, China

Full list of author information is available at the end of the article care $[1,2]$. However, posttransplant morbidity incidence remains high, which may affect the survival and quality of life of patients [3]. Thus, better understanding of the contributing factors for posttransplant morbidity is important.

The platelet is a primary factor in various physiological and pathological processes. Recent studies have demonstrated that platelet is involved not only in hemostasis and tissue repair [4], but also in tumor growth and metastasis [5, 6], ischemia/ reperfusion injury [7], and liver regeneration $[8,9]$. Patients with severe liver disease for 
liver transplantation have compromised platelet count and function [10]. These changes may contribute to the physiopathology of liver transplantation. Experimental and clinical studies investigated the role of platelet in candidates for liver transplantation point toward a dualistic result [11-13]. Although platelet is indispensable for liver tissue repair after liver transplantation, platelet can also contribute to graft injury through ischemia/ reperfusion injury. However, most of previous studies focused on platelet posttransplant, and the effect of preoperative platelet count on liver transplantation recipients has not been fully investigated. Therefore, this retrospective study aimed to determine the relationship between preoperative platelet count and outcome after adult liver transplantation.

\section{Methods}

\section{Patients and data sources}

We retrospectively assessed all adult patients (age $\geq 18$ years old) who received donation after cardiac death and underwent orthotopic liver transplantation (OLT) from January 2015 to September 2018 at the First Affiliated Hospital, Xi'an Jiaotong University. This paper complies with the STROBE reporting guideline for observational studies.

Clinical data of these patients, including demographic features, donor information, perioperative laboratory values, intraoperative variables, and postoperative complications, were obtained from the electronic medical records. A total of 346 consecutive patients had undergone OLT in our hospital, of which 329 patients were included in this analysis. Patients with missing platelet count data $(n=3)$, re-transplantation $(n=8)$, and incomplete postoperative laboratory values $(n=6)$ were excluded from this study. This retrospective study was approved by our institutional review board (XJTU1AF2015LSL-057), and the requirement for informed consent was waived.

\section{Outcome parameters}

The median follow-up was 16.8 (interquartile range: 9.228.8 months. The primary outcome measure was portal vein complication, including portal vein thrombosis and portal vein stenosis, after OLT. Portal vein complication was diagnosed with ultrasonography and computed tomographic scan. The secondary outcomes were overall survival, hepatic artery thrombosis, biliary strictures, early allograft dysfunction (EAD), in-hospital mortality, prolonged intensive care unit (ICU) stay, and postoperative hospital stay.

EAD was defined as the presence of at least one of the following laboratory parameters 7 days after OLT: bilirubin $\geq 10 \mathrm{mg} / \mathrm{dL}$ on day 7 , international normalized ratio $\geq 1.6$ on day 7 , and alanine or aspartate aminotransferases $>2000 \mathrm{IU} / \mathrm{L}$ within the first 7 days [14]. Prolonged ICU stay was defined as postoperative stay in the ICU for more than 7 days [15].

\section{Statistical analysis}

Categorical variables were reported as numbers and percentages and compared by the chi-squared analysis or Fisher's exact test as appropriate. Continuous data were tested by the Kolmogorov-Smirnov test for normality. Normally and abnormally distributed variables were expressed as mean \pm standard deviation (SD) and median (interquartile range, IQR) and were compared by Student's $t$-test and Mann-Whitney rank-sum test, respectively. The optimal cut-off value of preoperative platelet count was calculated by receiver operating characteristic (ROC) curve analysis by using the Youden index according to the incidence of portal vein complication after OLT. Kaplan-Meier estimation and log-rank test were used to analyze the overall survival between different groups. Univariate and multivariate analyses of prognostic factors were performed using logistic regression analysis.

The inverse probability of treatment weighting (IPTW) method was used in this study to reduce the bias in patient selection. We conducted a logistic regression model to estimate propensity scores. The covariates in the model included donor age, recipient body mass index, red blood cell count, leukocyte count, lymphocyte count, total bilirubin, albumin, prothrombin time (PT), activated partial thromboplastin time (APTT), model for end-stage liver disease (MELD) score, coexisting conditions, operation time, anhepatic phase, intraoperative blood loss, total input quantity, and cold ischemia time. Propensity scores were estimated for each patient, and stabilized IPTW weights were created [16]. The detailed method of IPTW was described in our previous study [15]. The power of our sample was $97 \%$ at an alpha of 0.05 , sample size of 167 and 162 in the high and low preoperative platelet count group respectively, and an odds ratio in the group proportions of 7.6. Two-sided $P$-values $<0.05$ were considered statistically significant. All statistical analyses were performed using SPSS Statistics 22.0 software (IBM Corporation, Armonk, NY, United States).

\section{Results}

\section{Patient demographics and cut-off value of preoperative platelet count}

Of the 329 patients included in this analysis, 248 were men $(75.4 \%)$, and 81 were women $(24.6 \%)$. The mean age was $46.71 \pm 0.55$ years. Pretransplant diagnosis included viral hepatitis $(n=170,51.7 \%)$, hepatocellular carcinoma $(n=95,28.9 \%)$, alcoholic cirrhosis $(n=8,2.4 \%)$, primary biliary cirrhosis or autoimmune liver disease 
$(n=20,6.0 \%)$, and other reasons $(n=36,11.0 \%)$. Thirtytwo patients died during the follow-up period. The median preoperative platelet count was $50 \times 10^{9} / \mathrm{L}$ (IQR, $34 \times 10^{9} / \mathrm{L}$ to $86 \times 10^{9} / \mathrm{L}$ ).

The diagnostic ability of preoperative platelet count for post-OLT portal vein complication was determined by ROC curve analysis. Based on the data, preoperative platelet count showed a good prediction ability for post-OLT portal vein complication (AUC $=0.705,95 \% \mathrm{CI}$ 0.613 to $0.797, p=0.001$ ). The optimal cut-off value for preoperative platelet count was $49.5 \times 10^{9} / \mathrm{L}$ with the maximum Youden index of 0.396 (sensitivity $=87.5 \%$, specificity $=52.1 \%$, Fig. 1). According to the cut-off value, 167 patients $(50.8 \%)$ were assigned to the low platelet count group $\left(>49.5 \times 10^{9} / \mathrm{L}\right)$ and 162 patients (49.2\%) were assigned to the high platelet count group $\left(\leq 49.5 \times 10^{9} / \mathrm{L}\right)$. The distribution of preoperative platelet count for each patient in different groups was shown in Figure S1.

\section{Baseline characteristics}

The baseline variables of the two groups are shown in Table 1. The donor age was a little younger in the high platelet count group (45.22 \pm 1.16 years old) than in the low platelet count group ( $46.12 \pm 1.12$ years old). Patients in the high platelet count group had a higher blood cell counts $(p<0.001)$ and higher rate of hypertension $(12 \% \mathrm{vs}$ $9.3 \%, p=0.002)$ and preoperative splenectomy ( $12 \%$ vs. $4.9 \%, p=0.022)$. However, PT, APTT, and MELD scores were significantly higher in the low platelet count group

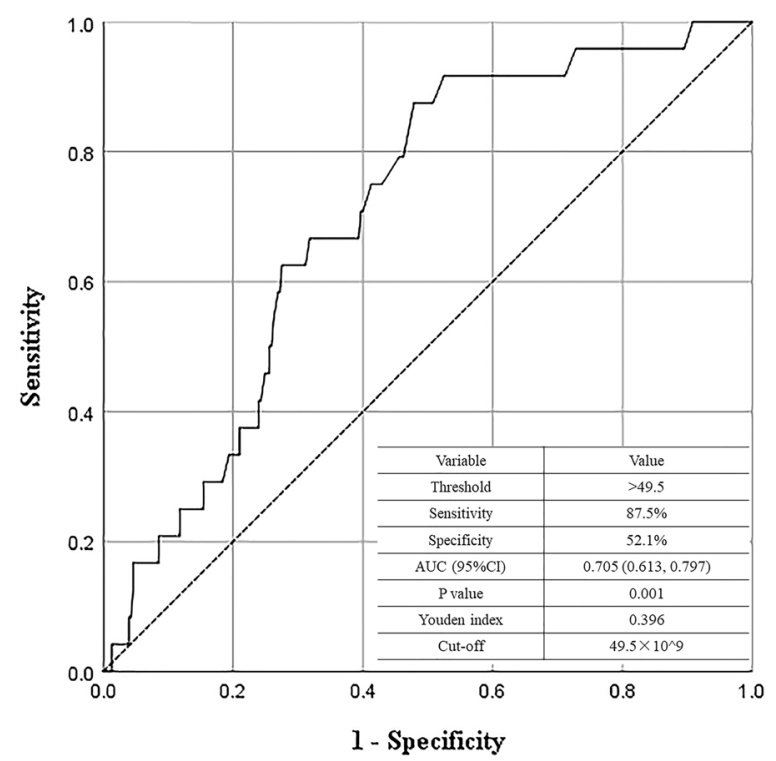

Fig. 1 Determination of optimal preoperative platelet count cut-off value by receiver operating characteristic analysis $(p<0.05)$. In terms of intraoperative variables, patients in the low platelet count group experienced a longer operation time $(p=0.014)$, a longer anhepatic phase $(p=0.006)$, and more blood loss and total input amount $(p<0.001)$. Other parameters analyzed had no significant differences between the two groups (Table 1).

\section{Postoperative outcomes}

Postoperative outcomes are shown in Table 2. Portal vein complication occurred in 24 patients after OLT (7.29\%). Twenty-one patients (12.6\%) in the high platelet count group developed postoperative portal vein complication compared with the three patients $(1.9 \%)$ in the low platelet count group. The difference was statistically significant (OR 7.623, 95\%CI 2.227 to 26.091, $p<0.001$ ). KaplanMeier analysis showed comparable overall survival rate between the two groups $(\log \operatorname{rank} p=0.774$, Fig. 2). Similarly, the incidence of hepatic artery thrombosis, biliary stricture, EAD, in-hospital mortality, and prolonged ICU stay did not show significant difference between the two groups. In addition, multivariable regression was used to adjust the imbalance in potential confounding variables. In the multivariable analysis, high preoperative platelet count was independently associated with a higher incidence of postoperative portal vein complication (OR $8.821,95 \%$ CI 2.260 to $34.437, p=0.002$, Table 2 ).

\section{Baseline characteristics and postoperative outcomes after IPTW analysis}

After IPTW adjustment, the baseline variables between the high platelet count group and low platelet group were comparable (Table 3). As regards postoperative outcomes, the patients in the high platelet count group had higher incidence of portal vein complication (OR 8.296, 95\%CI 1.855 to $37.096, p=0.001$ ) and EAD (OR $1.925,95 \%$ CI 1.098 to $3.374, p=0.022$ ) than those in the low platelet count group. After adjustment by the multivariable regression logistic analysis, the risk of portal vein complication (OR 9.210, 95\% CI 1.907 to 44.498, $p=0.006$ ) and EAD (OR 2.087, 95\% CI 1.131 to 3.853, $p=0.019)$ was also higher in the high platelet count group (Table 4).

\section{Discussion}

High morbidity rate remains an unsolved problem that affects the overall survival of patients who underwent liver transplantation. Thus, better understanding of the risk factors associated with posttransplant morbidity is important to improve the prognosis of these patients. Our current data demonstrated the independent association of preoperative platelet count with posttransplant morbidity. In this study, we found that the risk of posttransplant portal vein complication 
Table 1 Characteristics of demographic and clinical features of the patients

\begin{tabular}{|c|c|c|c|}
\hline Variables & $\begin{array}{l}\mathrm{PLT}>49.5 \times 10^{\wedge} 9 / \mathrm{L} \\
(n=167)\end{array}$ & $\begin{array}{l}\mathrm{PLT} \leq 49.5 \times 10^{\wedge} 9 / \mathrm{L} \\
(n=162)\end{array}$ & $P$ value \\
\hline \multicolumn{4}{|l|}{ Donor features } \\
\hline Donor age (years) & $45.22 \pm 1.16$ & $46.12 \pm 1.12$ & 0.009 \\
\hline Donor gender (male/female) & $122 / 45$ & $126 / 36$ & 0.32 \\
\hline Donor BMI (kg/m2) & $22.08(20.07,24.24)$ & $22.04(19.59,24.18)$ & 0.469 \\
\hline \multicolumn{4}{|l|}{ Demographic features } \\
\hline Age (years) & $47.98 \pm 0.74$ & $45.18 \pm 0.81$ & 0.609 \\
\hline Gender (male/female) & $142 / 25$ & $141 / 21$ & 0.60 \\
\hline $\mathrm{BMI}(\mathrm{kg} / \mathrm{m} 2)$ & $22.05(20.28,24.22)$ & $22.86(20.70,24.88)$ & 0.053 \\
\hline \multicolumn{4}{|l|}{ Clinical features } \\
\hline \multicolumn{4}{|l|}{ Preoperative laboratory values } \\
\hline Creatinine $(\mu \mathrm{mol} / \mathrm{L})$ & $60.00(45.50,68.40)$ & $55.00(46.00,69.00)$ & 0.556 \\
\hline BUN (mmol/L) & $4.54(3.52,6.61)$ & $4.66(3.72,6.10)$ & 0.525 \\
\hline Red cell $\left(\times 10^{12} / \mathrm{L}\right)$ & $3.44(3.05,4.17)$ & $3.08(2.73,3.83)$ & $<0.001$ \\
\hline Leukocyte $\left(\times 10^{9} / \mathrm{L}\right)$ & $4.63(3.35,6.54)$ & $3.01(2.11,4.41)$ & $<0.001$ \\
\hline Lymphocyte $\left(\times 10^{9} / \mathrm{L}\right)$ & $0.80(0.48,1.35)$ & $0.47(0.30,0.70)$ & $<0.001$ \\
\hline $\operatorname{ALT}(U / L)$ & $33.83(23.00,65.00)$ & $31.50(23.00,48.75)$ & 0.204 \\
\hline $\mathrm{AST}(\mathrm{U} / \mathrm{L})$ & $44.00(31.00,82.00)$ & $42.00(30.00,62.75)$ & 0.103 \\
\hline Total bilirubin $(\mu \mathrm{mol} / \mathrm{L})$ & $35.60(20.20,83.90)$ & $54.35(30.00,112.15)$ & 0.002 \\
\hline Albumin $(g / L)$ & $36.90(32.71,42.75)$ & $34.35(31.20,39.00)$ & 0.005 \\
\hline $\mathrm{PT}(\mathrm{s})$ & $17.20(15.05,19.55)$ & $19.15(17.50,21.88)$ & $<0.001$ \\
\hline APTT $(s)$ & $43.00(39.00,47.90)$ & $48.05(42.80,52.60)$ & $<0.001$ \\
\hline \multicolumn{4}{|l|}{ Hepatic features } \\
\hline MELD & $11.00(7.00,17.00)$ & $13.50(9.00,19.00)$ & 0.043 \\
\hline Etiology & & & 0.031 \\
\hline Viral hepatitis (\%) & $73(43.7 \%)$ & 97 (59.9\%) & \\
\hline Alcoholic cirrhosis (\%) & $3(1.8 \%)$ & $5(3.1 \%)$ & \\
\hline Hepatocellular carcinoma (\%) & $59(35.3 \%)$ & $36(22.2 \%)$ & \\
\hline $\begin{array}{l}\text { Primary biliary cirrhosis \& Autoimmune liver } \\
\text { disease (\%) }\end{array}$ & $12(7.2 \%)$ & $8(9.8 \%)$ & \\
\hline Other (\%) & $20(12.0 \%)$ & $16(9.9 \%)$ & \\
\hline \multicolumn{4}{|l|}{ Coexisting conditions } \\
\hline Smoking (\%) & $56(33.5 \%)$ & $50(30.9 \%)$ & 0.605 \\
\hline Drinking (\%) & $25(15.0 \%)$ & $36(22.2 \%)$ & 0.091 \\
\hline Hypertension (\%) & $20(12.0 \%)$ & $5(3.1 \%)$ & 0.002 \\
\hline Diabetes (\%) & $20(12.0 \%)$ & $15(9.3 \%)$ & 0.424 \\
\hline Pre-operative PVT (\%) & $32(19.2 \%)$ & $25(15.4 \%)$ & 0.372 \\
\hline Pre-operative splenectomy (\%) & $20(12.0 \%)$ & $8(4.9 \%)$ & 0.022 \\
\hline \multicolumn{4}{|l|}{ Intraoperative factors } \\
\hline Operation time (min) & $360.00(320.00,420.00)$ & $390.00(343.75,421.25)$ & 0.014 \\
\hline Anhepatic phase (min) & $47.00(43.00,54.00)$ & $50.00(45.00,57.25)$ & 0.006 \\
\hline Intraoperative blood loss (mL) & $1000(600,2000)$ & $1500(837.50,2850.00)$ & $<0.001$ \\
\hline Total input amount (mL) & $5370(4500,6585)$ & $6080(5235,8094)$ & $<0.001$ \\
\hline Warm ischemia time (min) & $14.00(10.00,15.00)$ & $14.00(10.00,15.00)$ & 0.733 \\
\hline Cold ischemia time (h) & $6.00(5.00,6.00)$ & $6.00(4.00,6.00)$ & 0.091 \\
\hline
\end{tabular}

was greater in patients with high preoperative platelet count $\left(>49.5 \times 10^{9} / \mathrm{L}\right)$ after adjustment for confounders in the multivariable regression. Furthermore, a high preoperative platelet count showed an independent association not only with posttransplant portal vein complication but also with EAD after reducing the selection bias 
Table 2 Primary and secondary outcomes in two groups

\begin{tabular}{|c|c|c|c|c|c|c|}
\hline \multirow[t]{2}{*}{ Outcomes } & \multirow{2}{*}{$\begin{array}{l}\mathrm{PLT}>49.5 \times 10^{\wedge} 9 / \mathrm{L} \\
(n=167)\end{array}$} & \multirow{2}{*}{$\begin{array}{l}\mathrm{PLT} \leq 49.5 \times 10^{\wedge} 9 / \mathrm{L} \\
(n=162)\end{array}$} & \multicolumn{2}{|c|}{ Univariate analysis } & \multicolumn{2}{|c|}{ Multivariable analysis } \\
\hline & & & $p$ & OR $(95 \% \mathrm{CI})$ & $p$ & OR $(95 \% \mathrm{Cl})$ \\
\hline Portal vein complications (\%) & $21(12.6 \%)$ & $3(1.9 \%)$ & $<0.001$ & $7.623(2.227,26.091)$ & 0.002 & $8.821(2.260,34.437)$ \\
\hline Hepatic artery thrombosis (\%) & $5(3.0 \%)$ & $4(2.5 \%)$ & 0.770 & $1.219(0.321,4.623)$ & & \\
\hline Biliary strictures (\%) & $22(13.2 \%)$ & $22(13.6 \%)$ & 0.914 & $0.966(0.512,1.822)$ & & \\
\hline Early allograft dysfunction (\%) & $36(22.0 \%)$ & $26(16.4 \%)$ & 0.203 & $1.439(0.822,2.518)$ & & \\
\hline In-hospital mortality (\%) & $9(5.4 \%)$ & $6(3.7 \%)$ & 0.464 & $1.481(0.515,4.260)$ & & \\
\hline Prolonged ICU stay (\%) & $74(44.3 \%)$ & $63(38.9 \%)$ & 0.319 & $1.250(0.806,1.940)$ & & \\
\hline Post-operative hospital stay (days) & $17(14,22)$ & $18(14,24)$ & 0.445 & / & & \\
\hline
\end{tabular}

Abbreviations: ICU intensive care unit

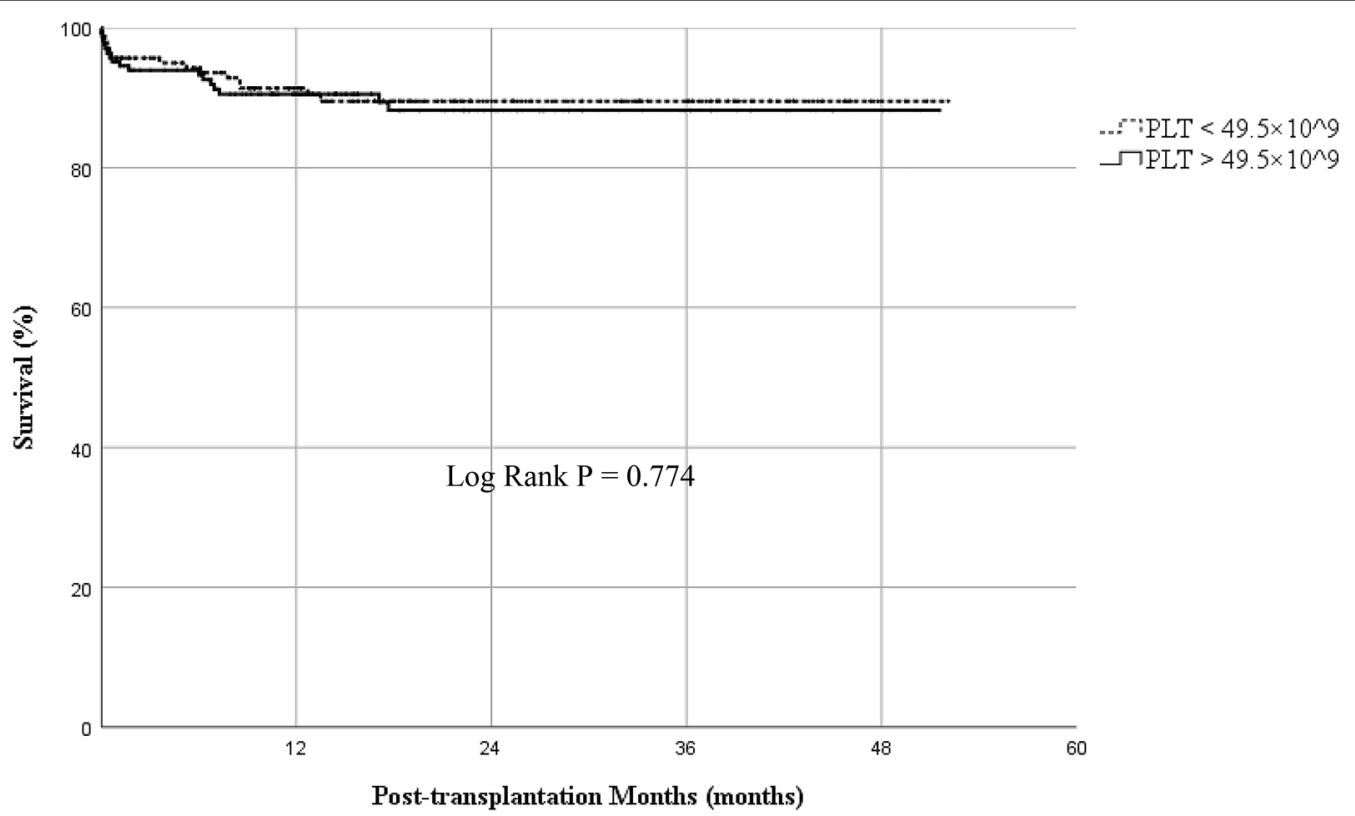

Fig. 2 Kaplan-Meier estimation of overall survival according to preoperative platelet count

with IPTW analysis. To the best of our knowledge, this study is the first to assess the effect of preoperative platelet count on posttransplant outcomes in liver transplant patients by using the IPTW method.

Platelet is critically important in hemostasis and thrombosis. Normally, hemostasis is tightly regulated and stabilized to prevent blood loss in the case of vessel wall damage [17]. In liver transplant recipients with chronic or acute liver disease, various alterations in primary and secondary hemostatic processes may occur $[18,19]$. These alterations may disturb the hemostatic balance of prohemostatic and antihemostatic factors and lead to bleeding or thrombotic disorders [20, 21]. In this study, preoperative thrombocytopenia was observed in liver transplantation recipients (median:
$50 \times 10^{9} / \mathrm{L}$ ), and among these patients, the risk of postoperative portal vein complication was higher in patients with high preoperative platelet count. This result may be illustrated on the one hand by the alteration of platelet function in these liver transplant recipients. Studies revealed that platelet function in flowing blood is not impaired in cirrhosis patients, and the thrombocytopenia status could be balanced by elevated platelet adhesive protein von Willebrand factor (vWF) level and the inhibition of its regulator [10, 22, 23]. vWF plasma levels can be elevated more than 10 -fold in these patients, thereby supporting platelet adhesion under flow conditions [11]. Therefore, patients with high preoperative platelet count on the basis of thrombocytopenia may have a higher risk of thrombosis 
Table 3 Characteristics of demographic and clinical features of the patients after IPTW

\begin{tabular}{|c|c|c|c|}
\hline Variables & $\begin{array}{l}\mathrm{PLT}>49.5 \times 10^{\wedge} 9 / \mathrm{L} \\
(n=167)\end{array}$ & $\begin{array}{l}\mathrm{PLT} \leq 49.5 \times 10^{\wedge} 9 / \mathrm{L} \\
(n=162)\end{array}$ & $P$ value \\
\hline \multicolumn{4}{|l|}{ Donor features } \\
\hline Donor age (years) & $47.04 \pm 1.15$ & $46.58 \pm 1.26$ & 0.772 \\
\hline Donor gender (male, \%) & $152(86.4 \%)$ & $120(86.3 \%)$ & 0.993 \\
\hline Donor BMI (kg/m2) & $22.49(20.52,24.22)$ & $22.86(20.64,24.69)$ & \\
\hline \multicolumn{4}{|l|}{ Demographic features } \\
\hline Age (years) & $47.39 \pm 0.70$ & $45.30 \pm 0.87$ & \\
\hline Gender (male, \%) & $136(77.3 \%)$ & $109(78.4 \%)$ & 0.808 \\
\hline $\mathrm{BMI}(\mathrm{kg} / \mathrm{m} 2)$ & $22.80(20.20,24.22)$ & $22.05(19.68,24.32)$ & 0.542 \\
\hline \multicolumn{4}{|l|}{ Clinical features } \\
\hline \multicolumn{4}{|l|}{ Preoperative laboratory values } \\
\hline Creatinine $(\mu \mathrm{mol} / \mathrm{L})$ & $59.72(44.74,72.00)$ & $56.00(47.00,66.37)$ & 0.552 \\
\hline BUN (mmol/L) & $4.40(3.38,6.93)$ & $4.77(3.88,6.10)$ & 0.954 \\
\hline Red cell $\left(\times 10^{12} / \mathrm{L}\right)$ & $3.57(3.04,4.01)$ & $3.29(2.82,3.97)$ & 0.012 \\
\hline Leukocyte $\left(\times 10^{9} / \mathrm{L}\right)$ & $3.57(2.77,5.43)$ & $3.27(2.35,5.37)$ & 0.119 \\
\hline Lymphocyte $\left(\times 10^{9} / \mathrm{L}\right)$ & $0.58(0.45,1.03)$ & $0.53(0.34,0.89)$ & 0.351 \\
\hline $\operatorname{ALT}(U / L)$ & $35.11(21.00,70.00)$ & $30.37(23.96,48.59)$ & 0.669 \\
\hline $\mathrm{AST}(\mathrm{U} / \mathrm{L})$ & $44.00(31.00,85.00)$ & $42.66(29.00,63.00)$ & 0.915 \\
\hline Total bilirubin $(\mu \mathrm{mol} / \mathrm{L})$ & $41.73(23.85,110.03)$ & $55.20(28.76,114.20)$ & 0.333 \\
\hline Albumin $(g / L)$ & $36.82(32.71,41.80)$ & $35.75(31.80,41.14)$ & 0.190 \\
\hline $\mathrm{PT}(\mathrm{s})$ & $18.14(15.51,21.42)$ & $18.50(16.90,21.80)$ & 0.389 \\
\hline APTT $(s)$ & $45.00(39.50,50.20)$ & $47.25(41.76,52.22)$ & 0.904 \\
\hline \multicolumn{4}{|l|}{ Hepatic features } \\
\hline MELD & $12.00(6.74,19.15)$ & $13.00(9.00,17.00)$ & 0.713 \\
\hline Etiology & & & 0.298 \\
\hline Viral hepatitis (\%) & $84(47.7 \%)$ & $83(59.7 \%)$ & \\
\hline Alcoholic cirrhosis (\%) & $6(3.4 \%)$ & $3(2.2 \%)$ & \\
\hline Hepatocellular Carcinoma (\%) & $53(30.1 \%)$ & $33(23.7 \%)$ & \\
\hline $\begin{array}{l}\text { Primary biliary cirrhosis \& Autoimmune liver } \\
\text { disease (\%) }\end{array}$ & $9(5.1 \%)$ & $7(5.0 \%)$ & \\
\hline Other (\%) & $24(13.6 \%)$ & $13(9.4 \%)$ & \\
\hline \multicolumn{4}{|l|}{ Coexisting conditions } \\
\hline Smoking (\%) & $64(36.4 \%)$ & $39(28.1 \%)$ & 0.119 \\
\hline Drinking (\%) & $45(25.6 \%)$ & $29(20.9 \%)$ & 0.328 \\
\hline Hypertension (\%) & $11(6.3 \%)$ & $4(2.9 \%)$ & 0.259 \\
\hline Diabetes (\%) & $14(8.0 \%)$ & $14(10.1 \%)$ & 0.512 \\
\hline Pre-operative PVT (\%) & $33(18.6 \%)$ & $18(12.9 \%)$ & 0.172 \\
\hline Pre-operative splenectomy (\%) & $12(6.8 \%)$ & $8(5.8 \%)$ & 0.701 \\
\hline \multicolumn{4}{|l|}{ Intraoperative factors } \\
\hline Operation time (min) & $389.33(330.00,470.00)$ & $386.43(340.00,424.11)$ & 0.296 \\
\hline Anhepatic phase (min) & $49.00(44.00,57.00)$ & $49.00(45.00,57.00)$ & 0.285 \\
\hline Intraoperative blood loss (mL) & $1500.00(800.00,3000.00)$ & $1500.00(800.00,2573.16)$ & 0.564 \\
\hline Total input amount (mL) & $6072.43(4785.37,7820.00)$ & $6000.00(5120.00,7913.63)$ & 0.947 \\
\hline Warm ischemia time (min) & $12.00(6.74,19.15)$ & $13.00(9.00,17.00)$ & 0.617 \\
\hline Cold ischemia time (h) & $6.00(5.00,6.00)$ & $6.00(4.00,6.00)$ & 0.476 \\
\hline
\end{tabular}

because of higher platelet number and enhanced platelet function. On the other hand, the incidence of preoperative splenectomy was higher in the high preoperative platelet count group than in the low preoperative count group in our current study (12.0\% vs. $4.9 \%)$. The number of postoperative platelets in these patients may 
Table 4 Primary and secondary outcomes in two groups after IPTW

\begin{tabular}{|c|c|c|c|c|c|c|}
\hline \multirow[t]{2}{*}{ Outcomes } & \multirow{2}{*}{$\begin{array}{l}\mathrm{PLT}>49.5 \times 10^{\wedge} 9 / \mathrm{L} \\
(n=167)\end{array}$} & \multirow{2}{*}{$\begin{array}{l}\mathrm{PLT} \leq 49.5 \times 10^{\wedge} 9 / \mathrm{L} \\
(n=162)\end{array}$} & \multicolumn{2}{|c|}{ Univariate analysis } & \multicolumn{2}{|c|}{ Multivariable analysis } \\
\hline & & & $p$ & OR $(95 \% \mathrm{Cl})$ & $p$ & OR $(95 \% \mathrm{Cl})$ \\
\hline Portal vein complications (\%) & $18(10.2 \%)$ & $2(1.4 \% \%)$ & 0.001 & $8.296(1.855,37.096)$ & 0.006 & $9.210(1.907,44.489)$ \\
\hline Hepatic artery thrombosis (\%) & $6(3.4 \%)$ & $3(2.2 \%)$ & 0.514 & $1.549(0.365,6.577)$ & & \\
\hline Biliary strictures (\%) & $16(9.1 \%)$ & $18(12.9 \%)$ & 0.273 & $0.668(0.325,1.371)$ & & \\
\hline Early allograft dysfunction (\%) & $48(27.1 \%)$ & $22(15.8 \%)$ & 0.022 & $1.925(1.098,3.374)$ & 0.019 & $2.087(1.131,3.853)$ \\
\hline In-hospital mortality (\%) & $9(5.1 \%)$ & $4(2.9 \%)$ & 0.323 & $1.722(0.533,5.566)$ & & \\
\hline Prolonged ICU stay (\%) & $65(36.9 \%)$ & $48(34.5 \%)$ & 0.659 & $1.119(0.703,1.781)$ & & \\
\hline Post-operative hospital stay (days) & $19(14,23)$ & $18(14,23)$ & 0.964 & / & & \\
\hline
\end{tabular}

Abbreviations: ICU intensive care unit

recover faster, which may affect their coagulation status and increase the risk of thrombosis. Moreover, previous studies showed that the activated platelets after liver transplantation can release highly active microparticles and form pseudopods on their surface that promote their interaction with neutrophils and other immune cells [24]. These interactions may further promote the thromboinflammatory ability of platelets and lead to the incidence of portal vein complications.

In addition to the well-known role in hemostasis, blood platelet has various other nonhemostic functions. There is increasing evidence that platelet plays an important role in tissue regeneration, ischemia/ reperfusion injury, inflammation, tumor growth, and angiogenesis [25]. In patients who underwent liver transplantation, all these processes may be involved. Although many studies have investigated the relationship between platelet and prognostic outcomes posttransplant, whether platelet count has beneficial or detrimental effects on these outcomes remains unclear [11]. Lesurtel et al. conducted a retrospective study of 257 consecutive liver transplantation recipients to evaluate the value of platelet count in predicting short- and long-term outcomes after liver transplantation [26]. They found that platelet count $<60 \times 10^{9} / \mathrm{L}$ on postoperative day 5 (the $60-5$ criterion) is an independent factor for severe complications and early graft and patient survival. Similarly, low posttransplant platelet count is an independent predictor of grade IIIb/IV complications, biliary anastomotic stricture, and graft loss after transplantation in retrospective studies [2, 27-30]. On the contrary, positive association between high platelet count and posttransplant morbidity has also been reported. Han et al. found that high preoperative platelet count $\left(>75 \times 10^{9} / \mathrm{L}\right)$ is a better predictor of hepatocellular carcinoma recurrence after living donor liver transplantation compared with inflammation-based scores [31]. This result is in line with our results that high preoperative platelet count can serve as a predictor of poor prognosis after liver transplantation.

Despite our novel results, this study has several limitations. First, this study was conducted in a single transplant center with a small sample size. Therefore, the incidence of some posttransplant complications was too low to obtain a positive result. Second, because of the retrospective nature of this study, the results are subject to selection bias, and we could not eliminate the underlying confounders from unmeasured variables. Although IPTW analysis was used to reduce the selective bias, the results may be affected by unknown factors. Thus, a multi-center prospective study is needed to further illustrate the role of platelets on the prognosis of posttransplant patients. Additionally, we only evaluated the value of preoperative platelet count but not the change in posttransplant platelet count and the function of platelet. In the previous studies, low post-transplant platelet count was generally considered as a risk factor of post-transplant morbidity, which was not assessed in the current study. As such, the relation between preoperative platelet count and post-transplant platelet count needs to be further evaluated to clarified the comprehensive of platelet on the prognosis of patients with liver transplantation.

\section{Conclusions}

In conclusion, we evaluated the relationship between preoperative platelet count and outcome after adult liver transplantation and found that preoperative platelet count $>49.5 \times 10^{9} / \mathrm{L}$ was an independent risk factor for posttransplant portal vein complication and EAD. These findings suggest that high preoperative platelet count could be an adverse prognostic predictor for liver transplant recipients. 


\section{Supplementary Information}

The online version contains supplementary material available at https://doi. org/10.1186/s12876-020-01553-z.

Additional file 1: Figure S1. The distribution of preoperative platelet count for each patient. PLT, platelet count.

\section{Abbreviations}

OLT: Orthotopic liver transplantation; EAD: Early allograft dysfunction; ICU: Intensive care unit; SD: Standard deviation; ROC: Receiver operating characteristic; IPTW: Inverse probability of treatment weighting; PT: Prothrombin time; APTT: Activated partial thromboplastin time; MELD: Model for end-stage liver disease; vWF: von Willebrand factor.

\section{Acknowledgements}

Not applicable.

\section{Authors' contributions}

All authors helped to perform the research; QS.L. manuscript writing, performing data analysis; T.M. and Y.W. literature review, performing data analysis; FG.R and F.M. contribution to writing the manuscript, drafting conception; RQ.W., Y.L. and B.W. contribution to writing the manuscript, drafting conception and study design. The author(s) read and approved the final manuscript.

\section{Funding}

This study was supported by grants from the National Nature Science Foundation of China (No. 81870445) (design of the study and interpretation of data) and the National Natural Science Foundation of China (No. 81727802) (statistical analysis of data).

\section{Availability of data and materials}

All data generated or analyzed during this study are included in this published article and its supplementary information files.

\section{Ethics approval and consent to participate}

This retrospective study was approved by the institutional review board of the First Affiliated Hospital, Xi'an Jiaotong University (XJTU1AF2015LSL-057), and the informed consent is not required for this type of study. The permission to access the data used in this study was obtained from the institutional review board of the First Affiliated Hospital, Xi'an Jiaotong University.

\section{Consent for publication}

Not applicable.

\section{Competing interests}

The authors declare that they have no competing interests.

\begin{abstract}
Author details
${ }^{1}$ National Local Joint Engineering Research Center for Precision Surgery \& Regenerative Medicine, Shaanxi Provincial Center for Regenerative Medicine and Surgical Engineering, Institute of Advanced Surgical Technology and Engineering, The First Affiliated Hospital of Xi'an Jiaotong University, No. 277, West Yanta Road, Xi'an 710061, Shaanxi Province, China. ${ }^{2}$ Department of Hepatobiliary Surgery, First Affiliated Hospital, Xi'an Jiaotong University, Xi'an, Shaanxi Province, China.
\end{abstract}

Received: 2 June 2020 Accepted: 23 November 2020 Published online: 06 January 2021

\section{References}

1. Bachir NM, Larson AM. Adult liver transplantation in the United States. Am J Med Sci. 2012;343(6):462-9.

2. Akamatsu N, Sugawara Y, Kanako J, Arita J, Sakamoto Y, Hasegawa K, Kokudo N. Low platelet counts and prolonged prothrombin time early after operation predict the 90 days morbidity and mortality in livingdonor liver transplantation. Ann Surg. 2017;265(1):166-72.
3. Freise CE, Gillespie BW, Koffron AJ, Lok AS, Pruett TL, Emond JC, Fair JH, Fisher RA, Olthoff KM, Trotter JF, et al. Recipient morbidity after living and deceased donor liver transplantation: findings from the A2ALL retrospective cohort study. Am J Transplant. 2008;8(12):2569-79.

4. Gawaz M, Vogel S. Platelets in tissue repair: control of apoptosis and interactions with regenerative cells. Blood. 2013;122(15):2550-4.

5. Gay LJ, Felding-Habermann B. Contribution of platelets to tumour metastasis. Nat Rev Cancer. 2011;11(2):123-34.

6. Tesfamariam B. Involvement of platelets in tumor cell metastasis. Pharmacol Ther. 2016;157:112-9.

7. Parker RI. Etiology and significance of thrombocytopenia in critically ill patients. Crit Care Clin. 2012;28(3):399-411 vi.

8. Lesurtel M, Graf R, Aleil B, Walther DJ, Tian Y, Jochum W, Gachet C, Bader $\mathrm{M}$, Clavien PA. Platelet-derived serotonin mediates liver regeneration. Science. 2006;312(5770):104-7.

9. Matsuo R, Nakano Y, Ohkohchi N. Platelet administration via the portal vein promotes liver regeneration in rats after $70 \%$ hepatectomy. Ann Surg. 2011;253(4):759-63.

10. Witters P, Freson K, Verslype C, Peerlinck K, Hoylaerts M, Nevens F, Van Geet C, Cassiman D. Review article: blood platelet number and function in chronic liver disease and cirrhosis. Aliment Pharmacol Ther. 2008;27(11):1017-29.

11. Pereboom IT, Lisman T, Porte RJ. Platelets in liver transplantation: friend or foe? Liver Transpl. 2008;14(7):923-31.

12. Sindram D, Porte RJ, Hoffman MR, Bentley RC, Clavien PA. Platelets induce sinusoidal endothelial cell apoptosis upon reperfusion of the cold ischemic rat liver. Gastroenterology. 2000;118(1):183-91.

13. Lisman T, Porte RJ. Antiplatelet medication after liver transplantation: does it affect outcome? Liver Transpl. 2007;13(5):644-6.

14. Olthoff KM, Kulik L, Samstein B, Kaminski M, Abecassis M, Emond J, Shaked A, Christie JD. Validation of a current definition of early allograft dysfunction in liver transplant recipients and analysis of risk factors. Liver Transpl. 2010;16(8):943-9.

15. Wang Y, Li Q, Ma T, Liu X, Wang B, Wu Z, Dang S, Lv Y, Wu R. Transfusion of older red blood cells increases the risk of acute kidney injury after Orthotopic liver transplantation: a propensity score analysis. Anesth Analg. 2018;127(1):202-9.

16. Harder VS, Stuart EA, Anthony JC. Propensity score techniques and the assessment of measured covariate balance to test causal associations in psychological research. Psychol Methods. 2010;15(3):234-49.

17. Nachman RL, Rafii S. Platelets, petechiae, and preservation of the vascular wall. N Engl J Med. 2008;359(12):1261-70.

18. Lisman T, Leebeek FW, de Groot PG. Haemostatic abnormalities in patients with liver disease. J Hepatol. 2002;37(2):280-7.

19. Hugenholtz GGC, Porte RJ, Lisman T. The platelet and platelet function testing in liver disease. Clin Liver Dis. 2009;13(1):11-20.

20. Hartmann M, Szalai C, Saner FH. Hemostasis in liver transplantation: pathophysiology, monitoring, and treatment. World J Gastroenterol. 2016;22(4):1541-50

21. Takahashi K, Nagai S, Safwan M, Liang C, Ohkohchi N. Thrombocytopenia after liver transplantation: should we care? World J Gastroenterol. 2018;24(13):1386-97.

22. Lisman T, Adelmeijer J, de Groot PG, Janssen HL, Leebeek FW. No evidence for an intrinsic platelet defect in patients with liver cirrhosis-studies under flow conditions. J Thromb Haemost. 2006;4(9):2070-2.

23. Arshad F, Lisman T, Porte RJ. Hypercoagulability as a contributor to thrombotic complications in the liver transplant recipient. Liver Int. 2013;33(6):820-7.

24. Cho SY, Hur M. Expanded impacts of platelet functions: beyond hemostasis and thrombosis. Ann Lab Med. 2019;39(4):343-4.

25. Yun SH, Sim EH, Goh RY, Park Jl, Han JY. Platelet activation: the mechanisms and potential biomarkers. Biomed Res Int. 2016;2016:9060143.

26. Lesurtel M, Raptis DA, Melloul E, Schlegel A, Oberkofler C, El-Badry AM, Weber A, Mueller N, Dutkowski P, Clavien PA. Low platelet counts after liver transplantation predict early posttransplant survival: the $60-5$ criterion. Liver Transpl. 2014;20(2):147-55.

27. Ben Hamida C, Lauzet JY, Rezaiguia-Delclaux S, Duvoux C, Cherqui D, Duvaldestin P, Stephan F. Effect of severe thrombocytopenia on patient outcome after liver transplantation. Intensive Care Med. 2003;29(5):756-62. 
28. Beltrame P, Rodriguez S, Brandao ABM. Low platelet count: predictor of death and graft loss after liver transplantation. World $\mathrm{J}$ Hepatol. 2019;11(1):99-108.

29. Takahashi K, Nagai S, Putchakayala KG, Safwan M, Gosho M, Li AY, Kane WJ, Singh PL, Rizzari MD, Collins KM, et al. Prediction of biliary anastomotic stricture after deceased donor liver transplantation: the impact of platelet counts - a retrospective study. Transpl Int. 2017;30(10):1032-40.

30. Takahashi K, Nagai S, Putchakayala KG, Safwan M, Li AY, Kane WJ, Singh PL, Collins KM, Rizzari MD, Yoshida A, et al. Prognostic impact of postoperative low platelet count after liver transplantation. Clin Transpl. 2017;31(3):e12891.
31. Han S, Lee S, Yang JD, Leise MD, Ahn JH, Kim S, Jung K, Gwak MS, Kim GS, Ko JS. Risk of posttransplant hepatocellular carcinoma recurrence is greater in recipients with higher platelet counts in living donor liver transplantation. Liver Transpl. 2018;24(1):44-55.

\section{Publisher's Note}

Springer Nature remains neutral with regard to jurisdictional claims in published maps and institutional affiliations.
Ready to submit your research? Choose BMC and benefit from:

- fast, convenient online submission

- thorough peer review by experienced researchers in your field

- rapid publication on acceptance

- support for research data, including large and complex data types

- gold Open Access which fosters wider collaboration and increased citations

- maximum visibility for your research: over $100 \mathrm{M}$ website views per year

At BMC, research is always in progress.

Learn more biomedcentral.com/submissions 